\title{
The Sappanwood Extract Drying With Carrier Agent Under Air Dehumidification
}

\author{
M. Djaeni ${ }^{1}$, M.S. Triyastuti ${ }^{1}$, F.D. Utari ${ }^{1}$, A. N. Annisa ${ }^{1}$, D. A. Novita ${ }^{1}$
}

\begin{abstract}
The sappanwood extract enriched by brazilin can be used for a natural coloring agent in food and beverages. The extract is produced in the form of dry powder for consumer convenience as well as prolonging storage life. Currently, the sappanwood extract drying still deals with the product sticky that inhibit water transport in drying. As a result, the drying process needs long time to get the moisture content below $10 \%$. The extract drying with carrier agent is an option to break the product sticky and to enlarge the surface area for water transport. This paper discusses the effect of carrier agent arabic gum and maltodextrin on sappanwood extract drying with air dehumidification. As a response, the moisture content in the extract was observed every 15 minutes and the average drying rate was estimated. Results showed that, the carrier agent improves drying rate significantly. The average drying time can be 1 hours shorter than that of without a carrier agent. The drying process was faster at higher temperature.
\end{abstract}

Keywords — brazilin, dehumidification, tray dryer, zeolite.

Abstrak — Ekstrak kayu secang yang kaya akan brazilin dapat digunakan sebagai pewarna alami produk makanan dan minuman. Ekstrak ini diproduksi dalam bentuk bubuk kering untuk kenyamanan konsumen serta memperpanjang umur simpan. Saat ini, pengeringan ekstrak kayu secang masih terkendala dengan ekstrak yang lengket, sehingga menghambat perpindahan air dalam pengeringan. Akibatnya, proses pengeringan membutuhkan waktu lama untuk mendapatkan kadar air di bawah $10 \%$. Ekstrak pengeringan dengan carrier agent merupakan cara yang digunakan untuk memecah produk yang lengket dan memperbesar luas permukaan pada perpindahan air. Penelitian ini membahas pengaruh carrier agent gum arab dan maltodextrin pada pengeringan ekstrak kayu secang dengan dehumidifikasi udara. Sebagai indikator, setiap waktu 15 menit dilakukan pengamatan kadar air dan guna menghitung laju pengeringan. Hasil penelitian menunjukkan bahwa, carrier agent meningkatkan laju pengeringan secara signifikan. Waktu pengeringan dapat berlangsung 1 jam lebih cepat dibanding tanpa menggunakan carrier agent. Proses pengeringan lebih cepat pada suhu tinggi..

Kata Kunci-Brazilin, dehumidifikasi, tray dryer, zeolite.

\section{INTRODUCTION}

$\mathrm{T}$ he Caesalpinia sappan L. known as sappanwood contains natural coloring agent for food or beverage application. Like roselle, the sappanwood pigment is also red [1,2,3,4]. However, the kind of organic compound in the sappan and roselle is different. The red pigment in sappanwood, is called brazilin [4]. By oxidation, the brazilin can be converted, forming to brazilein. Both brazilin and brazilein are potential for antioxidants [3].

The brazilin can be separated from the sappanwood by water extraction. In the solution, brazilin extracts is sensitive to the temperature change, UV light, and $\mathrm{pH}$. At $\mathrm{pH}$ 6-7, the pigment produces a red color, but at $\mathrm{pH}$ upper 7, the color changes to the purplish red. Meanwhile, at acid solution for example at $\mathrm{pH}$ of 2-5, it changes to yellow [5]. [5] Adawiyah and Indriati, and [6] Maharani stated at a temperature $100^{\circ} \mathrm{C}$, the color in brazilin solution changes. The same phenomena occurs, when the brazilin solution is irradiated for 72 hours [7].

So, in order to prolong the storage time of brazilinpigment, it was necessary to store the extract in dry powder with moisture content below $10 \%$. However, the sappanwood drying is not easy since it is sticky during the process. The extract also contains long chain organic compound that inhibits moisture transport.

${ }^{1}$ M. Djaeni, M.S. Triyastuti, F.D. Utari, A. N. Annisa, and D. A. Novita are with Departement of Chemical Engineering, Faculty of Engineering, Universitas Diponegoro, Semarang, 95618, Indonesia. Email: m.djaeni@undip.ac.id.
The drying under air dehumidification can be an option to speed up drying time [8]. The air dehumidification can improve the driving force for mass transfer from the surface product to the air. However, the air dehumidification, cannot change the matrix structure of the material in which enables to open the tissue of sappanwood extract or its fiber. Carrier agent, such as maltodextrin or arabic gum, can change or break the matrix structure. With this change, the way for water transport from inside to the surface can be opened, and the extract sticky can be reduced. As a result, more water can be evaporated.

This paper discusses the potential of carrier agents, namely arabic gum and maltodextrin for sappanwood extract drying under air dehumidification. The work aimed to evaluate the effect of this agent and temperature on sappanwood extract drying. As a response, the average drying rate was estimated and drying time was roughly predicted.

\section{METHOD}

The brazilin was extracted from sappanwood using hot water as a solvent at $80-90^{\circ} \mathrm{C}$. After 2 hours, the mixture was filtered to find the concentrated solution with sappanwood pigment [9]. The extract enriched by brazilin was mixed with maltodextrin (suppose $10 \%$ $\mathrm{w} / \mathrm{w}$ ). The mixture was then dried using the tray dryer to produce the dry extract (Figure 1). The dryer completed with zeolite to dehumidify air as drying medium. The sappanwood extract drying was performed in the procedures as presented in previous work [10]. 
Ambient air was passed through the adsorption column (A) containing $2 \mathrm{~kg}$ of the zeolite $3 \mathrm{~A}$ (Zeochem Switzerland). The air was dehumidified by zeolite and released adsorption heat. As a result, the humidity of air can be reduced up to $70-90 \%$ lower than that of intake. Next, the hot air entered the dryer to evaporate moisture from the extract. When the zeolite in column A was saturated, the adsorption process was shifted to adsorption column B. While, the column A was regenerated accordingly at $200^{\circ} \mathrm{C}$. As the responses, the powder size, final moisture, product dilution time were evaluated. The process was run for 90 minutes. These average drying rate was calculated based on the moisture content versus time. The procedures was repeated for different carrier agent (arabic gum 10\%).

\section{RESULT AND DISCUSSION}

\section{A. The presence of brazilin in sappanwood extract}

The presence of brazilin was analyzed by Gas Chromatography Mass Spectrometry (GCMS). The result showed that the 20 peaks appeared, in which indicating the functional groups, as illustrated in Fig. 2 [9]. The C-H-O group represented the brazilin compound bounded in C2-C16 chains. After drying, the similar peaks still appeared indicating the brazilin existence. Hence, the range of operational temperature was considered in the aspect of brazilin retention.

\section{B. Presence of Carrier Agent}

Figure 3 showed the sappanwood extract drying with and without a carrier agent at $50^{\circ} \mathrm{C}$. The result showed that with carrier agent, the evaporation rate of moisture in the extract increased significantly. As previously stated, the carrier agent can break the matrix structure of the extract. With this change, the extract can reduce the surface tension and sticky to form the small crystal or powder. Maltodextrin as a carrier agent can avoid particle agglomeration and encourage the crystal formation. The effects of agent was affected by operational temperature $[11,12,9]$. Meanwhile, the arabic gum also contributed to the water evaporation dominantly. Arabic gum formed the foam during the drying in which enlarge the surface area. Hence, the drying process was faster $[10,13,14]$. In this case, the effect of arabic gum was more superior compared to maltodextrin.

\section{Average drying rate estimation}

First, the drying rate was estimated with the equation 1 [8].

$r_{d r y}=k_{d r y}\left(q_{w, p}-q_{w, e}\right)$

Where, is the speed of water evaporation at time sampling (s-1), is the average contant of drying rate $(\mathrm{s}-1)$, is the moisture in product at real time (gram water per gram dry product), and is the moisture loaded in extract at equilibrium corresponding to operational dryer temperature. It was assumed that moisture at equilibrium for $50^{\circ} \mathrm{C} 0.02$ (since when the drying was continued, the moisture content in sappanwood closed to 0.02)

The estimation showed that without carrier agent, the average of drying rate was $1.32 \times 10-3 \mathrm{~s}-1$. The drying was too difficult due to the product sticky.
With the value, duirng 90 minutes, the extract cannot be fully dried (water content in extract was still $75 \%$ or 3.00 dry basis). Meanwhile, the extract with carrier agent showed the attractiveness in drying rate. For example with maltodextrin, the drying rate can be speeded up significantly (rounding 1.77x10-3s-1). During 90 minutes, the water in the extract can be removed from about $91 \%$ to $50 \%$ (around 1.00 dry basis). The stronger effect was showed by arabic gum with drying rate $1.80 \times 10-3 \mathrm{~s}-1$. With higher drying rate, the extract can be fully dried below $30 \%$ (or 0.40 dry basis). The result was inline with the previous works $[10,13,14]$.

\section{Effect of Air Temperature}

Air temperature affected the driving force for drying. With higher temperature, the relative humidity of air becomes lower, in wich reduces the moisture loaded at equilibrium. Hence, the mass transfer of air was enhanced as can be seen with higher moisture removal from product $[13,15]$. In addition, by increase of temperature, the moisture diffusivity from inside to surface of the product is higher. This fact can improve the mass transfer of water as formulated in Sherwood number [10], see also Fig. 4.

The results of sappanwood extract drying was still in line with the above statement. Here, with the same foaming agent addition (10\%), the water removal increased corresponding to the increase of temperature. With the same operational time (suppose 60 minutes), the moisture content in higher operational temperature was lower, as presented in Fig. 4.Based on the Fig. 4, the drying rate was estimated with the equation 1 [8]. It was assumed that moisture at equilibrium for $50^{\circ} \mathrm{C}$ was 0.05 (since when the drying was continued, the moisture content in sappanwood closed to 0.05). While, at higher temperature $\left(60^{\circ} \mathrm{C}\right.$ and $70^{\circ} \mathrm{C}$ ), the moisture content was proportionally decreased.

Results showed that the drying rate increased linearly with the increase of temperature. At operational temperature $50^{\circ} \mathrm{C}$, the drying rate was $1.80 \times 10-3 \mathrm{~s}-1$, while at $60^{\circ} \mathrm{C}$ and $70^{\circ} \mathrm{C}$, the estimated drying rate were $1.83 \times 10-3 \mathrm{~s}-1$, and $1.87 \times 10-3 \mathrm{~s}-1$, respectively. The improvement is still positive to reduce the drying time.

\section{CONCLUSION}

Sappanwood extract drying has been conducted in tray dryer under air dehumidification using different a carrier agent. The carrier agent, namely maltodextrin and arabic gum were introduced to reduce the agglomeration, and stickiness of the product. Using operational temperature $50^{\circ} \mathrm{C}$ for 90 minutes, with arabic gum, the sappanwood extract can be fully dried. While, with maltodextrin, the improvement for water evaporation was also significant. The drying time can be reduced up to a half hour with an increase of $10^{\circ} \mathrm{C}$ higher.

\section{REFERENCE}

[1] K. Duangmal, B. Saicheua and S. Sueeprasan, "Colour Evaluation of Freeze-Dried Roselle Extract as A Natural Food Colorant in A Model System of A Drink," LWT - Food Science and Technology, vol. 41, no. 8, p. 1437-1445, 2008. 
[2] P.-J. Tsai, J. McIntosh, P. Pearceb, B. Camden and B. R. Jordan, "Anthocyanin and Antioxidant Capacity in Roselle (Hibiscus Sabdariffa L.) Extract," Food Research International, vol. 35, no. 4, p. 351-356, 2002.

[3] P. Wetwitayaklung, T. Phaechamud and S. Keokitichai, "The Antioxidant Activity of Caesalpinia sappan L. Heartwoodin Various Ages," Naresuan University Journal, vol. 13, no. 2, pp. 43-52, 2005.

[4] S. Badami, S. Moorkoth and B. Suresh, "Caesalpinia Sappan A Medicinal and Dye Yielding Plant," Natural Product Radiance, vol. 3, no. 2, pp. 75-82, 2004.

[5] D. R. Adawiyah and I. Indriati, "Color Stability of Natural Pigment from Secang Woods (Caesalpinia sappan L.)," in The 8th Asean Food Conference, Hanoi, 2003.

[6] K. Maharani, "Stabilitas Pigmen Brazilin pada Kayu Secang (Caesalpinia sappan L.)," Fakultas Teknologi Pertanian, Institut Pertanian Bogor, Bogor, 2003.

[7] R. Holinesti, "Studi Pemanfaatan Pigmen Brazilein Kayu Secang (Caesalpinia sappan L.) sebagai Pewarna Alami Serta Stabilitasnya pada Model Pangan," Jurnal Pendidikan dan Keluarga, vol. 1, no. 2, pp. 11-21, 2009.

[8] M. Djaeni, S. B. Sasongko, A. P. A, X. Jin and A. J. v. Boxtel, "Carrageenan Drying with Dehumidified Air: Drying Characteristics and Product Quality," International Journal of Food Engineering, vol. 8, no. 3, 2012.

[9] M. Djaeni, M. S. Triyastuti, N. Asiah, A. N. Annisa and D. A. Novita, "The Effect of Air Temperature on The Sappanwood Extract Drying," in International Conference on Chemical and Material Engineering, Semarang, 2015.
[10] M. Djaeni, A. Prasetyaningrum, S. B. Sasongko, W. Widayat and C. L. Hii, "Application of Foam-Mat Drying with Egg White for Carrageenan: Drying Rate and Product Quality Aspects," Journal of Food Science and Technology, vol. 52, no. 2, pp. 1170-1175, 2015.

[11] B. R. Bhandaria, N. Dattaa and T. Howes, "Problems Associated With Spray Drying Of Sugar-Rich Foods," Drying Technology: An International Journal, vol. 15, no. 2, pp. 671684, 1997.

[12] S. Singh and D. Dixit, "A Review on Spray Drying: Emerging," International Journal of Applied Engineering and Technology, vol. 4, no. 1, pp. 1-8, 2014.

[13] P. Rajkumara, R. Kailappana, R. Viswanathan and G. S. V. Raghavan, "Drying Characteristics of Foamed Alphonso Mango Pulp in A Continuous Type Foam Mat Dryer," Journal of Food Engineering, vol. 79, no. 4, p. 1452-1459, 2007.

[14] T. Kudra and C. Ratti, "Foam-Mat Drying: Energya and Cost Analysis," Canadian Biosystems Engineering, vol. 48, pp. 3.27-3.32, 2006

[15] R. Thuwapanichayanan, S. Prachayawarakorn and S Soponronnarit, "Drying Characteristics and Quality of Banana Foam Mat," Journal of Food Engineering, vol. 86, no. 4, p. 573-583, 2008 .

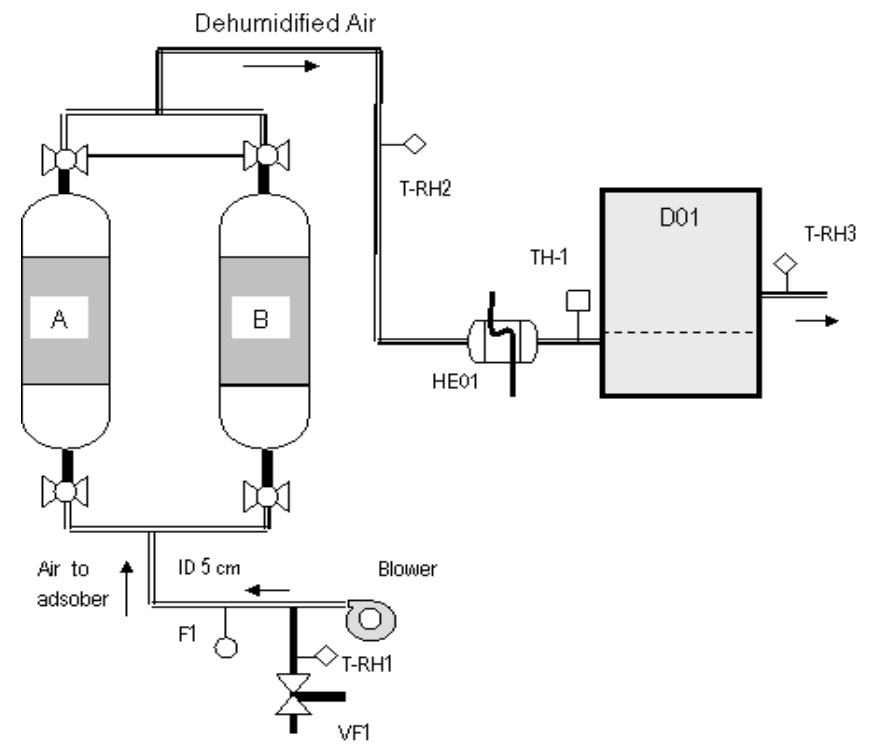

Figure 1. The Schematic overview of the experimental drying equipment (Internal diameter of columns A and B is $0.12 \mathrm{~m}$, diameter of piping is $0.05 \mathrm{~m}$, tray dryer size $0.40 \times 0.25 \times 0.60 \mathrm{~m}$ )

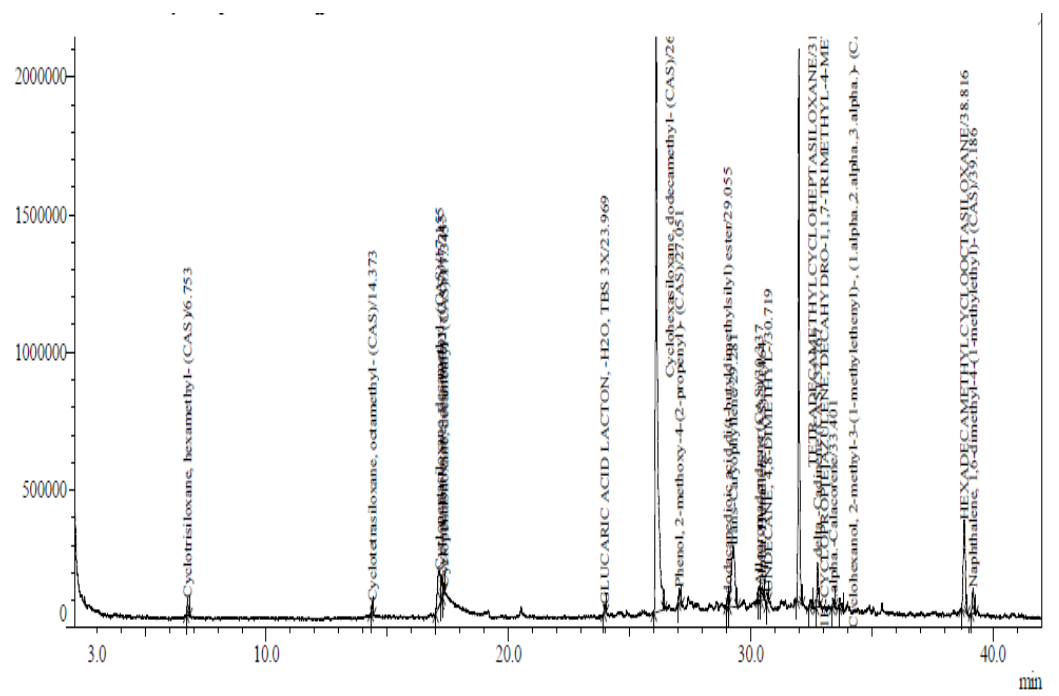

Figure 2. The Chromatography Mass Spectrometry (GCMS) for identifying brazilin in dry sappanwood extract [9]. 


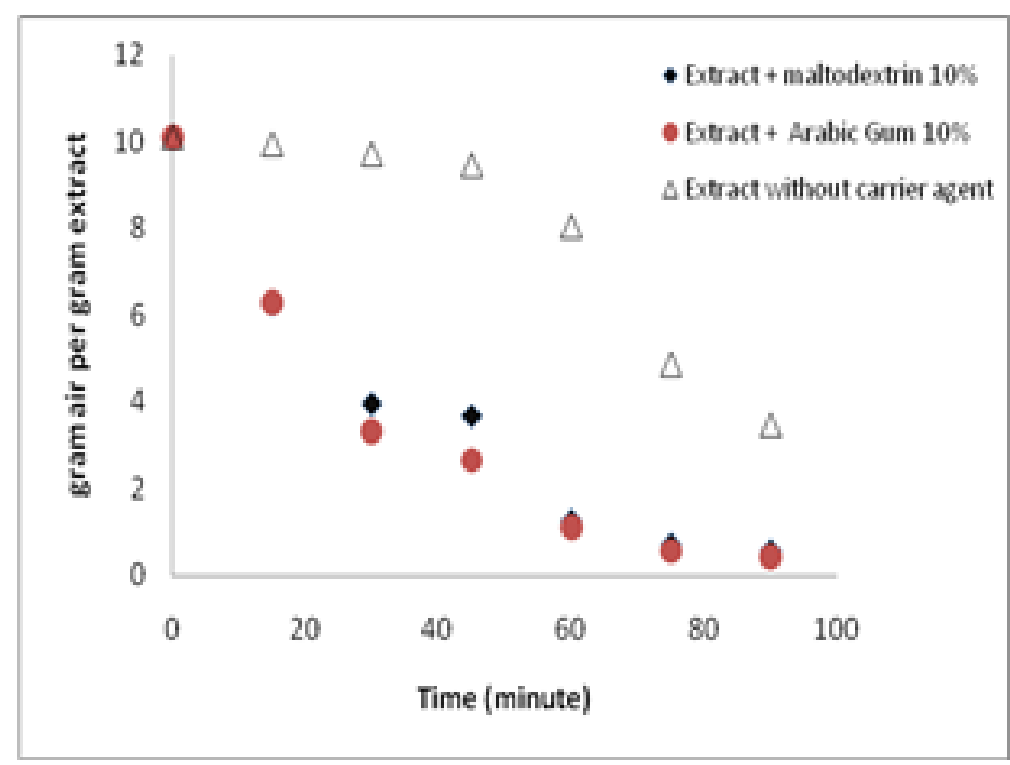

Figure 3. The The profile of moisture versus time in sappanwood extract drying with and without carrier agent at $50^{\circ} \mathrm{C}$.

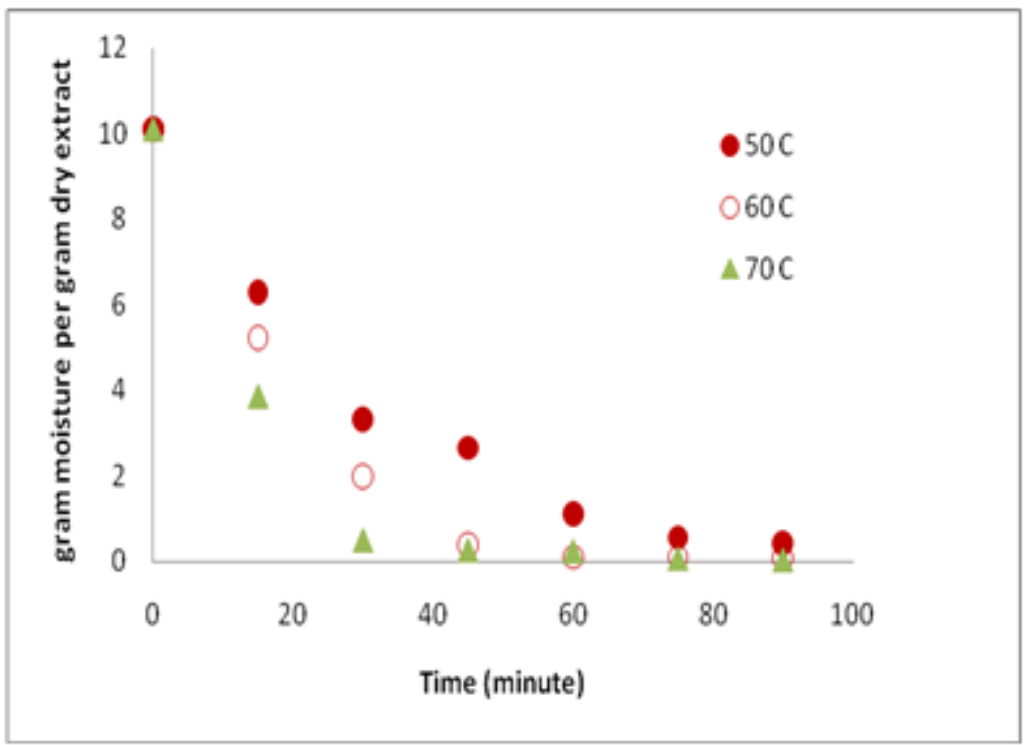

Figure 4. The profile of moisture versus time in sappanwood extract drying with arabic gum $10 \%$ at different. 